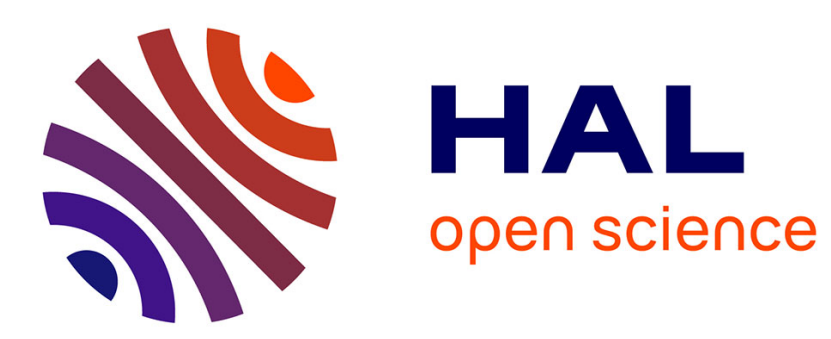

\title{
Beneficial or biohazard? How the media frame biosolids
} J. Robyn Goodman, Brett P. Goodman

\section{To cite this version:}

J. Robyn Goodman, Brett P. Goodman. Beneficial or biohazard? How the media frame biosolids. Public Understanding of Science, 2006, 15 (3), pp.359-375. 10.1177/0963662506062468 . hal-00571092

\section{HAL Id: hal-00571092 \\ https://hal.science/hal-00571092}

Submitted on 1 Mar 2011

HAL is a multi-disciplinary open access archive for the deposit and dissemination of scientific research documents, whether they are published or not. The documents may come from teaching and research institutions in France or abroad, or from public or private research centers.
L'archive ouverte pluridisciplinaire $\mathbf{H A L}$, est destinée au dépôt et à la diffusion de documents scientifiques de niveau recherche, publiés ou non, émanant des établissements d'enseignement et de recherche français ou étrangers, des laboratoires publics ou privés. 


\title{
Beneficial or biohazard? How the media frame biosolids
}

\author{
J. Robyn Goodman and Brett P. Goodman
}

This study looked at how the media framed biosolids, or treated sewage sludge, from 1994 to 2004 by analyzing the 13 media frames found in 286 biosolid-related articles from newspapers in Florida, Virginia, and California. The researchers found the articles framed biosolids as a regulatory or legal issue most often, and most of the frames' tones were neutral $(1,958)$. However, negative tone (507) happened three times more often than positive tone (149), and environmental, management, and public nuisance framing tended to be more negative than any of the other frames. Neither the frames themselves nor the tones had statistically significant changes over the past decade. Regarding the sources used in the stories, the most frequent source was local government officials, which were used twice as frequently as any other source, followed by corporations (16 percent) and citizens (14 percent). These findings should help biosolid producers and officials in developing a media strategy that is proactive toward shaping public opinion rather than reactive to an issue that makes its way to the media and spurs public concern.

\section{Introduction}

Throughout history, the ability to treat and distribute potable water and collect and treat wastewater has been essential to preserving public health and safety and protecting the environment. As of 2000, there were 16,255 publicly owned treatment works (POTWs) serving approximately 207.8 million people in the United States (USEPA, 2000a: 3-3). The Environmental Protection Agency (EPA) estimates that 275 million people will be served by a POTW by 2016 (USEPA, 2000b: B-3). With the nation's increasing dependence on centralized wastewater treatment facilities, the disposal or re-use of wastewater has become a critical issue in many communities.

The two primary products of wastewater treatment are the liquid effluent, and the semisolid residual material known as treated sewage sludge or biosolids. To create these products, most domestic wastewater treatment involves the synthesis of several physical, biological and chemical processes. The primary biological process, known as activated sludge, involves providing a favorable environment for microorganisms to breakdown the incoming waste stream. Once the microorganisms have consumed the waste, the biomass is separated through clarification or decanting resulting in treated water and a semi-solid residual. The treated water is often discharged to a water body, used for industrial purposes, 
or supplied for irrigation in accordance with applicable regulations. The semi-solid residuals, or biosolids, undergo treatment and are typically land applied as fertilizer, incinerated, or land-filled (see Tchobanoglous et al., 2003 for a comprehensive discussion of wastewater treatment).

In the United States, the use and disposal of treated biosolids are regulated by the United States Environmental Protection Agency (USEPA) under 40 CFR Part 503. The 503 regulations separate biosolids into two classifications: Class A and Class B. The primary distinction between the two classes is the allowable densities of pathogens (disease-causing organisms) in the treated sewage sludge. If pathogens are below detectable levels, the biosolids meet the Class A designation. Biosolids meeting the Class B requirements have been treated to reduce pathogens to levels beyond the threat to public health and the environment (USEPA, 2003: 14). Class A biosolids have no disposal restrictions, whereas the disposal of Class B biosolids is restricted to prevent the public's exposure until natural processes such as heat, sunlight, desiccation, and microbial competition further reduce pathogens to protective levels (USEPA, 2003: 15).

The EPA estimates that approximately 6.9 million dry tons of biosolids were generated in 1998 of which approximately 60 percent were re-used through composting, land application, or other beneficial uses (USEPA, 1999: 2). The volume of biosolids produced from municipal wastewater treatment will escalate to 8.2 million dry tons by 2010 , increasing the percentage of biosolids beneficially re-used to 70 percent (USEPA, 1999: 2). Of the 6.9 million dry tons, approximately 2.8 million dry tons are Class B biosolids and land applied (USEPA, 1999: 26). The demand for more land application sites continues to grow with the increasing volume of biosolids.

The beneficial properties of biosolids as soil amendment are well recognized, but land application of biosolids is often hindered by the lack of public acceptance (USEPA, 1999: 38-9). Throughout the 1990s, public acceptance efforts stressed proactively communicating with the public and its "gatekeepers" by conveying scientific data and information on the beneficial uses of biosolids (Beecher et al., 2004: I-2). In 1996, the National Academy of Sciences conducted a review of the 503 regulations and concluded that biosolids recycling involved minimal risk (NRC, 1996). Although biosolids producers used the report to support their activities and gain acceptance, public opposition continued and became more organized and involved at the local, state and federal levels. In 2002, the National Research Council surmised that "there is no documented scientific evidence that the Part 503 rules has failed to protect public health. However, additional scientific work is needed to reduce persistent uncertainty about the potential for adverse human health effects from the exposure to biosolids" (NRC, 2002: 4). This overarching finding has further galvanized both supporters for and opponents of biosolids land applications.

The ability to market biosolids and their beneficial re-use to the public is a driving force in addressing the growing need for treatment and disposal of the public's wastewater. Although public education focused on scientific results has increased public acceptance, it has also increased the public's skepticism about the risks of biosolids to public health and the environment (Beecher et al., 2004: I-9). The biosolids industry is recognizing that continued public acceptance is gained through building relationships and earning public trust (Beecher et al., 2004: I-15). Organizations such as the National Biosolids Partnership ${ }^{1}$ are developing programs focused on developing environmental management systems for biosolids producers to implement with the goals of earning public confidence and gaining public acceptance through responsible management (USEPA, 1999: 33). As with other industries with perceived risk, shaping public perception is a critical component of gaining public trust and acceptance (e.g., Siegrist and Cvetkovich, 2000; Wakefield and Elliott, 
2003; Lindsay et al., 2000; Goldstein, 1998; Logan, 1995). Generally, when the public evaluates risk, they use qualitative factors such as dreaded outcome, unfamiliarity, catastrophic potential, feeling of involuntariness, and uncertainty about the future, and these factors will heighten their risk perceptions (Wakefield and Elliott, 2003; Pidgeon et al., 1999; Beecher et al., 2004).

The media are one of the major influences on public perceptions and one of the main transmitters and sources of the public's risk information (Bennett, 1999; Wakefield and Elliott, 2003; Frewer et al., 2002; Lindsay et al., 2000). For example, social amplification of risk theory suggests that the way the media cover an issue, including amount of coverage and/or the media's framing of the industry or event, is one of the most important determinants of the amplification or attenuation of perceptions of risk (Kasperson et al., 1988; Pidgeon et al., 1999). As Nelkin (1989) notes, the way the media cover an issue may affect how an industry is regulated, the outcomes of risk-related litigation, and the direction of research and development. Moreover, one of the most comprehensive overviews on the public's perceptions of biosolids said: "local newspapers have played a significant role in affecting public knowledge, opinions, perceptions, and behavior around local biosolids recycling programs" (Beecher et al., 2004: II-28).

Thus, from biosolids advocates' and producers' perspectives, studying the media's coverage and framing of biosolids is the vital first step toward understanding how the public's perception is formed and changed over time. Furthermore, few people have direct experience with environmental issues such as biosolids, most people receive their environmental news from the media, and researchers have found that the media's selection and emphasis on aspects of an issue define that issue for the public particularly when the public's level of personal experience with the topic is limited as is the case with biosolids (e.g., Salmone and Greenberg, 1990; Nelkin, 1995; Greenberg et al., 1989; Hester and Gonzenbach, 1995; Lundy and Irani, 2002; Bridges and Nelson, 2000). Consequently, understanding how the media present biosolids to the public will provide a foundation for developing communication strategies to promote public relationships, earn public confidence and potentially gain public acceptance. The purpose of this paper, then, is to look at how the media frame biosolids for the public in order to develop better communication strategies for biosolids producers and advocates.

\section{Media framing: a conceptual framework}

Media framing focuses on the specific way issues are presented and how public issues are expressed to the audience (Tankard et al., 1991; Entman, 1993). As media researchers have noted, framing is the key to how journalists organize news (Cappella and Jamieson, 1997). Journalists must transform unusual or unfamiliar issues into easily understandable stories, and by doing so, they often present the issue(s) in familiar themes, or frames (Huxford, 2000: 188). Through their selective representation of certain aspects of an issue, frames provide audiences with a cognitive framework for understanding the issue. Thus, media frames privilege certain realities over others (e.g., Gamson and Modigliani, 1989; Entman, 1993). As Entman notes, the "analysis of frames illuminates the precise way in which influence over a human consciousness is exerted by the transfer (or communication) of information" (1993: 56). Therefore, framing provides a logical conceptual framework for exploring how the media define biosolids to the public because framing is fundamental to public opinion formation (e.g., Iyenger and Kinder, 1987; Brosius and Kepplinger, 1990; Bridges and Nelson, 2000; Gamson, 1989; Andsager, 2000). 
Even though framing "can observe recurring patterns in the news and can find a structure in its content" (Gans, 1979: 6), the conceptual definitions of frames and framing are often vague within this fragmented body of literature (Scheufele, 1999; Tankard et al., 1991; Entman, 1993). Many framing theorists see framing as the selection and salience of attributes of an issue for inclusion on the media agenda, which is the tradition this paper will follow (Entman, 1993). According to Entman (1993), "to frame is to select some aspects of a perceived reality and make them more salient in a communicating text, in such a way as to promote a particular problem definition, causal interpretation, moral evaluation, and/or treatment recommendation" (p. 52), while Tankard et al. (1991) see "a frame [as] a central organizing idea for news content that supplies a context and suggests what the issue is through the use of selection, emphasis, exclusion, and elaboration" (p. 11). Thus, a media frame is an organizing idea that gives context and uses exclusion, selection, emphasis, and elaboration to talk about the issue. Its purpose is interpretational: to define problems, diagnose causes, make moral judgments, and suggest remedies (Entman, 1993).

According to Ghanem (1997), there are four major dimensions to media frames: subtopic, or what is included in the frame; framing mechanisms such as size and placement; cognitive elements, or details of the subtopics; and affective elements, or tone. Given that "people evaluate information regarding uncertain (risky) alternatives in terms of either potential gains (positive framing) or potential losses (negative framing) and those preferences can be altered by changing the way information is presented" (Kahneman and Tversky, 1979: 267; also Grantham and Irani, 2004), this analysis was particularly interested in subtopics and affective elements.

\section{Literature review}

Many researchers agree that framing is important to risk communication because what is included and excluded often defines the issues and risks for the public thereby affecting their perceptions (e.g., Lundy and Irani, 2002; Bridges and Nelson, 2000; Andsager, 2000). In fact, studies have found that audiences often think about issues as they are framed in the media (Pan and Kosicki, 2001). In terms of science/health and environmental media framing studies, researchers have looked at issues ranging from manufacturing and nuclear power accidents and old-growth forests to nuclear power and water quality (Palenchar, 2001; Gamson and Modigliani, 1989; Ryan et al., 1991; Driedger and Eyles, 2003; Liebler and Bendix, 1996).

Several framing studies have generally looked at how the media covered environmental, science and health issues. Griffin and Dunwoody (1997) studied newspaper coverage of environmental risks and found that political or governmental frames were undoubtedly the most common frames. Collins and Kephart (1995) looked at the concept of biological diversity in newspaper and magazine stories and found a limited set of commonly used frames. They found the most prominent frame to be the "Race Against the Clock frame," accounting for 61 percent of the stories. This frame focused on "a seemingly irreversible trend toward extinction" and inextricably linked humans to biodiversity (Collins and Kephart, 1995: 37). The next most commonly used frame was the Economy versus the Environment ( 23 percent). According to the authors, this frame pitted the economy against the environment by presenting them as an either-or proposition and tended to privilege the economy over the environment (pp. 38-9). The final frame, Political Wrangling, found in 16 percent of the stories, explored how biodiversity was used by various presidencies for political gain. 
Driedger and Eyles (2003) studied the framing of chlorinated drinking water in Canada and its potential link to cancer. The media mostly framed chlorine as causing cancer (76 articles) followed by chlorine saves lives (37), chlorine is the "hearse" option of disinfection (13), and chlorine is a dangerous time bomb (12) (Driedger and Eyles, 2003: 1288). However, in the 76 cancer-related articles, 34 mentioned somewhere that chlorination was protective and prevents illness, but the other articles didn't emphasize its necessity and 15 cases mentioned no chlorination benefits.

Spratt (2001) analyzed the New York Times and three magazines: Scientific American, Science, and The Survey for their framing of the 1918 flu epidemic. She found that three of the four publications framed the epidemic as government fighting to control flu from spreading, whereas Scientific American framed it "as one between men of science and biological forces" (Spratt, 2001: 74). Yet, all the publications used biomilitaristic language highlighting man battling disease.

Rather than creating a list of commonly used media frames, Huxford (2000) studied the use of a specific type of frame-science fiction frames - in the media's coverage of cloning. In 204 articles on cloning from Britain and the US, the author found that science fiction frames were present in 46 percent of the stories. The most commonly used science fiction frame was based on Aldous Huxley's Brave New World, which was used in 33 percent of the stories employing science fiction frames, followed by Mary Shelley's Frankenstein, with 21 references, and the movie The Boys from Brazil with 13 references. According to Huxford, the Frankenstein frame emphasized science out of control, whereas Brave New World emphasized controlled science (2000: 196). Furthermore, the newspaper frames dealt with fears surrounding cloning rather than examples or the actual act of cloning.

In looking at the general framing of science, health, and environmental stories, these studies showed a cross-study pattern of framing. The first frame tended to deal with political or governmental aspects, in particular how the government used the crisis or issue in the political arena or how the government was involved. Another commonality was the use of a danger or risk frame that emphasized the issue or event as endangering humans or the environment. The final commonality was a man versus nature frame. This frame described the issue or event as involving control whether it is man's lack of control over the situation or man's attempt to control the situation.

Aside from general framing findings, studies have shown that sources influence the type of media frames used. For example, Miller and Riechert (1997) showed that wetland frames changed for the Bush, Reagan, and Clinton administrations. Liebler and Bendix (1996) found in their study of the major television networks' coverage of the preservation of spotted owls and old-growth forests that most of the sources used a pro-cut frame four times more often than a pro-save frame, particularly when the sources emphasized economic conditions or traditional lifestyles. However, if the source was talking about scientific evidence or ethics, then a pro-save frame was used. Furthermore, the authors found that the reporter wrap-ups used the pro-cut frame four times more frequently than the pro-save frame, mimicking the source frames. Thus, it is likely that source usage will affect the type of frames reporters use.

\section{Biosolids and public perception}

Regarding this paper's specific issue, biosolids, there have been relatively few studies on biosolids and public perception. During the 1990s when biosolids became a more salient issue, local pockets of negative publicity due to poor biosolids' management or accusations of harm largely characterized the local public's perceptions (Beecher et al., 2004: II-6). 
Then, in 1995 and 1997, the publication of Toxic Sludge is Good for You (Stauber and Rampton, 1995) and "The Case for Caution: Recommendations for Land Application of Sewage Sludge" (Harrison et al., 1997) increased national public concern as well as producing a growth in media attention (Beecher et al., 2004: II-7). Since these publications 10 years ago, Dr. David Lewis's accusations against biosolids research have again heightened public concern. Lewis, a former EPA scientist, published papers that were critical of biosolids and theorized that they were causing serious health problems for those living near application sites.

Lindsay et al. (2000) conducted a more systematic and comprehensive study of a local group's perceptions of biosolids. They found New Hampshire residents' perceptions of the economic benefits, negative impacts, and potential risks influenced acceptance of biosolids. The residents' support of biosolids also was inversely related to the number of biosolids stories in the media. Thus, the authors concluded: "the media needs to ensure that its reports ... are accurate and reliable" (Lindsay et al., 2000: 94).

More recently, Beecher et al. (2004) conducted a nationwide survey on biosolids. They found the public supported biosolids recycling when there were clear benefits such as recycling nutrients or creating renewable energy. Their levels of concern were amplified when biosolids included industrial wastes or were from large cities such as New York but were attenuated when biosolids were supervised locally or they knew about the recycling program beforehand. They also distrusted any biosolids sources that had a profit motive.

\section{Method}

Because the framing of an issue often dictates people's definition of that issue and its risks, the framing of biosolids in the media is fundamental to public opinion (Andsager, 2000). Therefore, the following research questions were explored: how did the media define biosolids; how often did the media define the various classes of biosolids; how did the media frame biosolids; did these frames change over time; what was the tone of the major frames used; and did the tone change over time? Moreover, researchers have said that sources are allowed to control story frames (Dunwoody and Peters, 1993: 46; see also Corbett, 1998; Dunwoody and Ryan, 1987), so the researchers also looked at what sources were used.

To explore the research questions, a framing content analysis was conducted on newspaper articles from Florida, California, and Virginia from 1995 to $2004 .^{2}$ These states were chosen because, according to the USEPA, they represent some of the hotbeds of public debate between biosolid producers and public perception (J. Smith, 2004, personal communication). The time frame was chosen to match the period relating to federal regulatory changes with biosolids and to capture the period when biosolids become an environmental issue in each of the three states.

Articles were collected from the Lexis/Nexis database using full text searches with the following keywords: biosolid, sewage sludge, and sewage w/in 10 sludge. The researchers eliminated articles with fewer than 100 words, duplicate articles, articles that were indirectly related to biosolids such as sludge spills on highways or organic food articles, which only mentioned biosolids once, and opinion pieces. ${ }^{3}$ Thus, only articles that directly related to the recycling or disposal of biosolids were included for a total of 262 articles.

According to Tankard (2001: 102), the steps involved in a framing study are as follows: "Make the range of possible frames explicit, put the various possible frames in a manifest list, develop keywords, catchphrases and symbols to help detect each frame, ${ }^{4}$ use the frames in the list as categories in a content analysis, and get coders to code articles into categories." 
Following this protocol, the researchers randomly chose 10 percent of the articles to qualitatively develop a list of all the possible frames. This range of possible frames was used to code each story for the frame's presence. The researchers used Tankard's (2001: 101) framing mechanisms when coding each story for the frames' presences such as headlines, subheads, sources, quotations, concluding statements, and paragraphs of articles. When multiple frames were used in a story, the coders determined a primary frame (the most prominent frame throughout the story) and a secondary frame. Second, the researchers coded each article for the primary and secondary frames' tones. Because sometimes there is a mixture of tones within a given frame, the coders rated each paragraph in the article for tone and then averaged the scores (Tankard, 2001). ${ }^{5}$

The researchers, a mass communication researcher and an environmental engineer who specializes in biosolids, found 13 substantive frames: regulatory, litigation, farm, urban versus rural, public nuisance, health and safety, disposal, environment, economic, public perception, management, research, and debate (see Appendix A for descriptions). Tone was determined from the public's viewpoint: would this item alarm me (negative), comfort me (positive), or neither (neutral)? In addition to the frames, two independent coders coded for: newspaper name, state came from, page and section number, sources cited, and associated risks (see Appendix B for coding sheet).

Next, the researchers randomly chose 15 percent of the articles to establish intercoder reliability, which was $p=.87$, and confirm the original frame list. Finally, the two trained coders coded the population.

\section{Analysis}

Of the 262 articles analyzed, most were relatively short, either 0-499 words (43 percent) or 500-9999 words (43 percent). Section B (51 percent) had the most articles followed by A (16 percent) with more articles appearing on the front page (43 percent) than elsewhere. Wednesday was the most frequent day for biosolid articles to run (26 percent), followed by Tuesday (16 percent), Thursday (13 percent), Friday and Saturday (11 percent each), Sunday (9 percent), and Monday (6 percent). ${ }^{6}$ As for the breakdown of articles by year, 2002 had the most (20 percent), followed by 2001 (18 percent), 1998 (12 percent), 2000 (11 percent), 1997 and 2003 (8 percent each), 2004 (7 percent), 1995 and 1996 (6 percent each), and 1999 (5 percent). Furthermore, more articles came from California (52 percent) than from either Florida (19 percent) or Virginia (21 percent). There also was a dominance of biosolid articles in three papers: the Press Enterprise from Riverside, California (34 percent), the Richmond (VA) Times-Dispatch (13 percent), and the Sarasota (FL) Herald (12 percent).

The first research asked how the media defined biosolids. In the 262 articles, only 45 (17 percent) provided a definition of biosolids, and most of those definitions came from four newspapers: Sarasota Herald (31 percent), Press Enterprise (22 percent), Richmond TimesDispatch (18 percent), and the Associated Press wire service (11 percent). The definitions of biosolids varied based on the amount of information given in the definition and the positive or negative connotation of the definition. Many simply defined biosolids as "sewage sludge," "treated waste," "treated human excrement," "the dirt-like byproduct of sewage treatment," or a "mix of industrial and human waste." Others provided more specific information such as "the byproduct of a treatment process that removes fecal matter, foodstuffs, and other solids from wastewater," "treated sewer solids including human waste, paper products and ground-up vegetables," or "a mix of human and industrial waste used as fertilizer on nonedible crops." 
Within this range of definitions of biosolids, some newspapers defined it with a more positive or negative slant. Most of these types of definitions tended to be more negative such as: "pungent, dark sludge," "unsavory goop," "smelly muck," or "thick tar-like sludge that is laced with pathogens and stinks to high heaven." There were a few definitions that had more of a positive spin including "earthy, nutrient-rich byproduct of sewage treatment" or "usable product made from sewage sludge."

Similar to the instance in which biosolids were defined by the media, there were few instances where articles addressed and defined the various classes of biosolids. Of the 262 articles, only 32 (8 percent) defined any of the classes of biosolids. Again, most of these came from a handful of newspapers: 53 percent from the Sarasota Herald, 16 percent from the Press Enterprise, and 6 percent each from the Daily News of Los Angeles and the Palm Beach Post.

Regarding the actual framing of biosolids, the researchers conducted a factor analysis to group together like frames because the list of frames was so large and many consistently overlapped each other (Table 1). The factor analysis was remarkably clean and yielded five factors: environment/research (Env/Res), disposal/economic (Dis/Econ), management/public perception/public nuisance (Man/PP/PN), regulation/legal/debate (Reg/Leg/Deb), and farm/ urban versus rural/health and safety (Farm/UR/HS). Each of these frames made sense to both coders from a qualitative standpoint as well.

The third research question asked how the media framed biosolids. According to Table 2, two frames constituted the overall frame for 75 percent of the stories-Reg/Leg/Deb ( $N=128 ; 49$ percent of stories) and Man/PP/PN ( $N=70 ; 27$ percent of stories). After these frames, the remaining frames broke down as follows: Farm/UR/HS $(N=25 ; 10$ percent of stories), Dis/Econ ( $N=23 ; 9$ percent of stories), and Env/Res ( $N=13 ; 5$ percent of stories). As for use of secondary frames, three frames were essentially equally present and made up 75 percent of the secondary frames: Farm/UR/HS ( $N=63 ; 26$ percent $),$ Man/PP/PN $(N=62$; 26 percent), and Reg/Leg/Deb ( $N=59 ; 24$ percent). Thus, most journalists framed biosolids as a legal/regulatory issue or explored the effects on the public.

The next research question asked if the frames changed over time. There was no

Table 1. Factor analysis of frames-rotated component matrix ${ }^{\mathrm{a}}$

\begin{tabular}{|c|c|c|c|c|c|}
\hline & \multicolumn{5}{|c|}{ Component } \\
\hline & 1 & 2 & 3 & 4 & 5 \\
\hline Public nuisance & -.090 & -.060 & .686 & -.034 & .041 \\
\hline Regulation & .069 & -.037 & -.022 & .712 & .264 \\
\hline Environment & .800 & -.092 & .034 & -.092 & -.026 \\
\hline Health and safety & .366 & -.011 & -.019 & .209 & .580 \\
\hline Public perception & .071 & -.031 & .740 & -.047 & .069 \\
\hline Disposal & .067 & .762 & .024 & .030 & .170 \\
\hline Research & .851 & .013 & -.098 & .109 & .144 \\
\hline Economic & -.111 & .792 & .004 & -.135 & -.104 \\
\hline Management & -.077 & .419 & .648 & .207 & -.074 \\
\hline Debate & .435 & .148 & -.041 & .544 & .068 \\
\hline Legal & -.161 & -.143 & .073 & .586 & -.220 \\
\hline Farmers & .070 & .174 & .016 & .107 & .716 \\
\hline Urban versus rural & -.159 & -.157 & .119 & -.275 & .532 \\
\hline
\end{tabular}

Extraction method: principal component analysis. Rotation method: Varimax with Kaiser normalization.

a Rotation converged in six iterations. 
Table 2. Overall and secondary framing in biosolids stories

\begin{tabular}{lcllc}
\hline & $\begin{array}{l}\text { Percent of } \\
\text { stories as } \\
\text { overall frame }\end{array}$ & $\begin{array}{l}\text { Frequency as } \\
\text { secondary } \\
\text { frame }\end{array}$ & $\begin{array}{l}\text { Percent of } \\
\text { stories as } \\
\text { secondary } \\
\text { frame }\end{array}$ \\
\hline Env/Res & 13 & $5 \%$ & 21 & $9 \%$ \\
Dis/Econ & 23 & $9 \%$ & 38 & $16 \%$ \\
Man/PP/PN & 70 & $27 \%$ & 62 & $26 \%$ \\
Reg/Leg/Deb & 128 & $49 \%$ & 59 & $24 \%$ \\
Farm/UR/HS & 25 & $10 \%$ & 63 & $26 \%$ \\
\hline
\end{tabular}

significant change in the overall and secondary frames from 1995 to $2004\left(\chi^{2}=48.189\right.$, df $=36, p<.05$ and $\chi^{2}=46.703$, df $=36, p<.05$ respectively) ${ }^{7}$

The fifth research question asked what the overall frames' tones were. Overall there were 149 instances of positive framing $(M=.58, \mathrm{SD}=1.3), 1,958$ instances of neutral framing $(M=7.56, \mathrm{SD}=5.62)$, and 507 instances of negative framing $(M=2.0, \mathrm{SD}=3.02)$. Although most framing was neutral, negative framing happened three times as often as positive framing. Env/Res $(M=1.75, \mathrm{SD}=.22)$ and $\mathrm{Man} / \mathrm{PP} / \mathrm{PN}(M=1.76, \mathrm{SD}=.36)$ tended to be slightly more negative than Dis/Econ $(M=2.1, \mathrm{SD}=.3), \mathrm{Reg} / \mathrm{Leg} / \mathrm{Deb}(\mathrm{M}=$ $1.93, \mathrm{SD}=.19)$, and Farm/UR/HS $(M=1.91, \mathrm{SD}=.3)$, which all tended to be purely neutral on average.

Table 3 shows the frequency of the average tone for each frame. ${ }^{8}$ Four of the five frames had the majority of their stories having a neutral tone with the exception of Man/PP/ $\mathrm{PN}$, which had 45 percent neutral (as measured from 1.76 to 2.25). Man/PP/PN also had the greatest percentage of negative frames, accounting for one-quarter of its occurrences (range was 1-1.5) and Reg/Leg/Deb and Dis/Econ had the fewest (2.7 percent and 4 percent respectively). Regarding positive framing, Env/Res was never positively framed and Reg/ Leg/Deb was rarely positively framed (4.7 percent) compared to approximately one-third of the Dis/Econ framing.

The next research question asked if the tone of the frames changed over time. The oneway ANOVA showed that the tone did not change over time $(\mathrm{F}=.875$, $\mathrm{df}=9, p=\mathrm{n}$.s. $)$.

The final research question looked at the sources used. Table 4 shows the descriptive statistics for sources. The most frequent source was local government officials, which were used twice as frequently as any other source. Corporations (16 percent) and citizens (14 percent) were roughly equivalent in their mentioning followed by utilities with 9 percent.

Table 3. Frequency of average tones per frame

\begin{tabular}{llcccc}
\hline Average tone & Env/Res & Dis/Econ & Man/PP/PN & Reg/Leg/Deb & Farm/UR/HS \\
\hline $1-1.25$ & $1(7 \%)$ & $1(4 \%)$ & $5(7 \%)$ & $1(.7 \%)$ & $1(4 \%)$ \\
$1.26-1.5$ & $1(7 \%)$ & $0(0 \%)$ & $13(18 \%)$ & $3(2 \%)$ & $2(8 \%)$ \\
$1.51-1.75$ & $4(31 \%)$ & $1(4 \%)$ & $18(25 \%)$ & $18(14 \%)$ & $4(17 \%)$ \\
$1.76-2.0$ & $7(54 \%)$ & $12(52 \%)$ & $29(41 \%)$ & $96(75 \%)$ & $11(46 \%)$ \\
$2.01-2.25$ & $0(0 \%)$ & $3(13 \%)$ & $3(4 \%)$ & $4(3 \%)$ & $3(12.5 \%)$ \\
$2.26-2.5$ & $0(0 \%)$ & $6(26 \%)$ & $1(1 \%)$ & $5(4 \%)$ & $3(12.5 \%)$ \\
$2.51-2.75$ & $0(0 \%)$ & $1(4 \%)$ & $0(0 \%)$ & $1(.7 \%)$ & $0(0 \%)$ \\
$2.76-3.0$ & $0(0 \%)$ & $0(0 \%)$ & $2(3 \%)$ & $0(0 \%)$ & $0(0 \%)$ \\
\hline
\end{tabular}

Note: 1 = negative, 2 = neutral, 3 = positive; $\%$ of frame's total appearance. 
Table 4. Descriptive statistics for sources used

\begin{tabular}{|c|c|c|c|c|c|c|}
\hline Source type & Frequency & Mean & SD & Min. & Max. & $\begin{array}{l}\text { Percent of } \\
\text { total sources } \\
\text { used }\end{array}$ \\
\hline Local government & 392 & 1.5 & 1.9 & 0 & 14 & $28 \%$ \\
\hline State government & 66 & .27 & .85 & 0 & 7 & $4.8 \%$ \\
\hline Federal government & 52 & .20 & 69 & 0 & 5 & $3.8 \%$ \\
\hline Environmental or interest groups & 57 & .22 & .76 & 0 & 6 & $4.1 \%$ \\
\hline Farmers & 65 & .25 & 1.01 & 0 & 9 & $4.7 \%$ \\
\hline Educational institutions & 23 & .09 & .48 & 0 & 4 & $1.7 \%$ \\
\hline Corporations & 225 & .86 & 1.6 & 0 & 9 & $16.3 \%$ \\
\hline Utility & 119 & .46 & 1.3 & 0 & 8 & $8.6 \%$ \\
\hline Trade organizations & 3 & .02 & .15 & 0 & 2 & $.2 \%$ \\
\hline Citizens & 189 & .72 & 1.34 & 0 & 8 & $13.7 \%$ \\
\hline Non-affiliated scientist/expert & 49 & .19 & 1.09 & 0 & 11 & $3.6 \%$ \\
\hline Government scientist/expert & 19 & .07 & .46 & 0 & 6 & $1.4 \%$ \\
\hline Legal professional & 99 & .38 & 1.01 & 0 & 6 & $7.2 \%$ \\
\hline Medical professional & 9 & .03 & .24 & 0 & 2 & $.7 \%$ \\
\hline Other & 11 & .04 & .25 & 0 & 2 & $.8 \%$ \\
\hline
\end{tabular}

Part of the reason corporations were frequent sources was that many of the articles from California dealt with controversies surrounding one corporation, Synagro, that disposes of municipal biosolids.

\section{Discussion}

In looking at the media framing results and thinking about them in terms of how biosolids producers and advocates can develop communication strategies to promote public relationships, earn public confidence, and ultimately gain public acceptance, there were several interesting findings and points to be made. First, few articles provided a definition of biosolids, and when it was provided, the definitions were inadequate, potentially misleading, or often times negative sounding. Describing biosolids as "sewage sludge" doesn't provide enough information or context for the average citizen. It is doubtful that most people know or understand that wastewater is more than human waste, and from these types of definitions, most will think the article is talking about human excrement only, which already has the perception of being foul and disease-ridden. Moreover, biosolids are treated sewage sludge that, according to government set standards, has greatly reduced or no pathogens left.

When articles use descriptions such as "a mix of industrial and human waste," the industrial waste reference is quite vague and potentially misleading. Again, many are likely to have negative associations with the term "industrial waste" seeing industrial waste as synonymous for toxic waste, meaning it is a non-reusable contaminant that pollutes our environment and endangers human health.

Other definitions were simply pejorative in calling biosolids "unsavory" or "smelly." These types of definitions already paint an unpleasant picture in a reader's mind, and they may well cause a reader to tune out the benefits of biosolids. A few of the other definitions tended to be misleading. When an article says that biosolids are "full of pathogens," it implies that these are non-removable and biosolids are inherently dangerous. Given that people tend to remember the first and last things they read (Parkin, 1993) and that many of 
these definitions occur early in the story, it is likely that all readers remember are that biosolids are "full of pathogens" or "unsavory" regardless of what the rest of the article says. More comprehensive definitions that explain what constitutes biosolids, that explain biosolids are treated to regulated standards that protect human health and safety, and that convey the environmental and agronomic benefits of biosolids could help greatly with their image in the public's mind.

From the biosolids communication strategists' perspective, they cannot control how the media choose, or don't choose, to define biosolids. However, they can emphasize a more comprehensive definition to the public and media in their materials and ensure that biosolids advocates use comprehensive definitions when speaking to both the public and the media. Furthermore, given the large number of local government sources quoted in the media, strategists should emphasize the intricacies of biosolids, from a definitional standpoint, with these potentially influential sources.

Aside from the lack of defining biosolids, the researchers found that the most common overall frames were Reg/Leg/Deb and Man/PP/PN and the most common secondary frames were Reg/Leg/Deb, Man/PP/PN and Farm/UR/HS. The fact that these frames were the most common is not surprising given that all involve the conflict news value, one of the most frequently found news values in environmental stories and an impetus for most environmental issues coverage (Curtin and Rhodenbaugh, 1999; Bennett, 1999; Miller and Riechert, 2000).

In looking at these frames, the biosolids industry has direct control of management practices and regulatory compliance. The results support the effort within the industry to develop environmental management systems that provide an organizational framework for advancing good management practices and maintaining regulatory compliance (National Biosolids Partnership, "Mission Statement," www.biosolids.org). Another point of interest is that the Env/Res frame was the least likely to appear. Thus, the industry's investment in the science supporting the environmental benefits of biosolids is the topic least likely to be used by the media in communicating biosolids-related issues to the public.

The next research question asked if the frames changed over time. There was no significant change in the frames from 1995 to 2004. These results are surprising given that many longitudinal framing studies show some variation in frames over time (e.g., Gamson and Modigliani, 1989). Unfortunately for the biosolids communication strategists, the results reflect their inability to shift the public message to frames within their control and that potentially will support the beneficial uses of biosolids such as management, research, environment, economics, and disposal. However, the static nature of the frames provides the foundation for formulating a media strategy for biosolids. Since the key issues to be reported are known, preparation for media interviews should address these topics within the frames that are likely to emerge in the media coverage. In other words, when biosolids advocates use the common media frames, their quotations and information neatly fit within the journalists' framing of the situation potentially increasing the likelihood and frequency of journalists using the advocates' quotations, arguments, and general information.

Another focus of the research was to analyze tone. As with the media frames, the articles' tones surprisingly did not change over time. Since many longitudinal framing studies show some variation in frames' tones over time (e.g., Gamson and Modigliani, 1989) and there are efforts from the biosolids advocacy and opposition camps to shape tone, the results were unexpected. Moreover, negative framing happened three times as often as positive framing with Man/PP/PN having the greatest percentage of negative occurrences. The Man/PP/PN and the Env/Res tended to be the most negative. Env/Res was never positively framed and Reg/Leg/Deb was rarely positively framed although on 
the whole it was neutrally framed. The results again point to the importance of management and the industry's ineffective communication on the research and environmental aspects supporting biosolids. Good management equates to regulatory compliance. When biosolids are regulated appropriately, stories about poor management will not occur, which can only improve the industry's public image. However, it is unlikely that any amount of public relations efforts will remedy the public nuisance (i.e., odor, dust, flies) aspect to the Man/PP/PN frame.

Regarding the Env/Res negative tone, it may be a reflection of the media and the public's lack of knowledge, breeding skepticism of the biosolids industry as described by Beecher et al. (2004). Moreover, many times when this particular frame was negative, it was all from one source, a man the media called a "whistleblower," about what he perceived as inaccurate biosolids data. In terms of news values, this whistleblower will continue to be used as a source because he adds to the conflict of the issue. From the biosolids advocates' standpoint, the best they can do is push the numerous governmental and industry studies (WEF, 2005; USEPA, 2005) that demonstrate the benefits of properly managed biosolids land application and that show current regulations protect human health with the hopes that the media will balance this information with the whistleblower's information (NRC, 2002: 4).

The final research question looked at sources. The most frequent were local government followed by corporation and citizens. Other researchers have also found that most environmental sources tend to be from the government (e.g., Liebler and Bendix, 1996; Taylor et al., 2000). Furthermore, the high use of local governmental officials reveals them to be key gatekeepers. The biosolids industry needs to maintain relationships with these key public opinion leaders and nurture their understanding of biosolids in the hope that they will convey a balanced, scientifically based message to the media when interviewed for biosolids-related stories.

As for why the second most frequent source was corporate, many of the articles from California dealt with controversies surrounding Synagro, who disposes of municipal biosolids. Regarding the citizens, in most cases their statements were negative since most lived near a composting plant; their complaints were about odor or ill health effects that they linked to their proximity to biosolids.

The increasing need to treat and dispose of the US's biosolids is a critical issue faced by wastewater utilities. Although the wastewater and biosolids industry have invested in the science and technology that treat waste to levels the government has deemed protective of human health and demonstrated the beneficial uses of biosolids, lack of public acceptance is a primary factor in shaping the future of the wastewater utilities and their biosolids operations. The industry is beginning to understand that controversy regarding biosolids is more about the values and the interests of individuals and not about actual science (Jockers and Saroka, 2003: 6), and it is attempting to gain public acceptance through good management and public partnering in its research agenda (National Biosolids Partnership, www.biosolids.org; Dixon and Field, 2003; Beecher et al., 2004). The results of this research support this direction.

However, public perception is reality (Logan, 1995), and media framing is a major influence in shaping public perception (Lindsay et al., 2000; Goldstein, 1998; Logan, 1995) especially for a generally obscure, low-involvement topic such as biosolids. Therefore, understanding the media's role in gaining public acceptance will be a critical component to earning the public's trust and conveying the industry's emphasis on management. Knowing the persistent frames and the tones of these frames related to biosolids can be used to 
develop a media strategy that is proactive towards shaping public perception rather than reactive to an issue that makes its way to the media and spurs public concern.

Future research should look at whether this emphasis on environmental management and stakeholder involvement promoted by organizations such as the National Biosolids Partnership will result in a variation towards frames and tones favorable to the industry in the media and an increase in public acceptance.

\section{Appendix A: Frame explanation}

Regulatory: any federal, state or local laws and regulations, ordinances, zoning issues, enforcement of regulations, breaking regulations, regulation failures.

Litigation: court cases involving biosolids, damages related to legal rulings.

Farm: use on farms, biosolids as fertilizer, crops, soils, nutrients, and organic versus chemical fertilizers.

Urban versus rural: conflict between urban and rural areas, the shipping of urban waste to rural areas, and urban sprawl/population growth.

Public nuisance: odor, traffic, dust, and pests.

Health and safety: danger to people, metals, pathogens, and exposure.

Disposal: recycling of biosolids, landfills, incineration, and dumping.

Environment: threat and danger to it as well as pollution issues.

Economic: costs related to processing of biosolids and recycling and positive/negative economic impacts of biosolids.

Public perception: risky, uncertainty, unknown outcomes, hysteria, unwanted, and anger.

Management: processing of biosolids and mismanagement.

Research: industry sponsored and educationally sponsored, EPA's research, biases in research, doing appropriate research, claims of improper or faulty research, good research.

Debate: anything about the debate over biosolids in general, particularly when coverage is showing opposing sides on the issue.

\section{Appendix B}

\section{CODING SHEET}

\#

Newspaper name:

State article from:

California

Florida

Virginia

Day of the week: Mon Tue Wed. Thur. Fri. Sat. Sun.

$\begin{array}{llllllllllll}\text { Year: } & 94 & 95 & 96 & 97 & 98 & 99 & 00 & 01 & 02 & 03 & 04\end{array}$

Section of paper: $\begin{array}{lllllllllllllll} & \text { B } & \text { C } & \text { D } & \text { E } & \text { F }\end{array}$

Other

Page number:

Length in words: $\quad 0-499 \quad 500-999 \quad 1000-1499 \quad 1500+$ 
News sources (list number of times cited for each):

Local government

State government

Federal government

Environmental/interest groups

Farmers

Educational institutions

Corporation

Utility

Trade organization

General public

Non-affiliated scientist/expert

Government scientist/expert

Legal professional

Medical professional

Other

Frames used (note frequency and tone-positive/claming, neutral/balanced, negative/ alarming) a global attitude measure consisting of six 7-interval scales, including: negative/ positive, foolish/wise, worthless/valuable, unacceptable/acceptable, bad/good, and unfavorable/favorable.

\section{Notes}

1 The National Biosolids Partnership (www.biosolids.org) is an alliance formed in 1997 of the Association of Metropolitan Sewage Agencies, the Water Environment Federation and the United States Environmental Protection Agency.

21994 was dropped from the analysis because it only yielded two articles.

3 The authors eliminated opinion pieces because their purpose differs from that of news pieces (with opinion attempting to sway the audience and news presenting both sides in the most objective manner possible) and because of format differences.

4 The researchers also used Entman's suggestion of looking for "sentences that provide thematically reinforcing clusters of facts or judgments" to detect/identify frames (1993: 52).

5 The researchers justified coding each paragraph because a single word or phrase can work "as a cue that draws in an entire string of narrative and ideological themes, values and opinions" (i.e., frames) (Huxford, 2000: 188).

6 The percentages do not total $100 \%$ for several of these categories because there were wire articles that had no day of the week, page number, etc.

7 There were multiple cells with five or fewer observations. Because the results were insignificant under these conditions, no further collapsing of data was necessary.

8 This was calculated by multiplying the number of times a given tone was found by 1 (for negative), 2 (for neutral) or 3 (for positive). Thus a story with three instances of positive framing for Env/Res was coded as 9 .

\section{References}

Andsager, J.L. (2000) "How Interest Groups Attempt to Shape Public Opinion with Competing News Frames," Journalism and Mass Communication Quarterly 77(3): 577-92.

Beecher, N., Connell, B., Epstein, E., Flitz, J., Goldstein, N. and Lono, M. (2004) Public Perception of Biosolids Recycling: Developing Public Participation and Earning Trust. Alexandria, VA: Water Environment Research Foundation.

Bennett, P. (1999) "Understanding Responses to Risk," in P. Bennett and K. Calman (eds) Risk Communication and Public Health, pp. 3-19. Oxford: Oxford University Press.

Bridges, J.A. and Nelson, R.A. (2000). "Issues Management: A Relational Approach,” in S.D. Brunig (ed.) Public Relations as Relationship Management: A Relational Approach to the Study and Practice of Public Relations, pp. 95-115. Mahwah, NJ: Lawrence Erlbaum. 
Brosius, H. and Kepplinger, H.M. (1990) "The Agenda-setting Function of Television News: Static and Dynamic Views," Communication Research 17: 183-211.

Cappella, J. and Jamieson, K.H. (1997) Spiral of Cynicism: The Press and the Public Good. New York: Oxford University Press.

Collins, C.A. and Kephart, S.R. (1995) "Science as News: The Emergence and Framing of Biodiversity," Mass Communication Review 22(1-2): 21-45.

Corbett, J.B. (1998) "The Environment as Theme and Package on a Local Television Newscast," Science Communication 19(3): 222-37.

Curtin, P.A. and Rhodenbaugh, E. (1999) "It's Not Easy Being Green: Building the News Media Agenda on the Environment," paper presented at the Association for Education in Journalism and Mass Communication, New Orleans, LA.

Dixon, L.G. and Field, P.M. (2003) Proceedings from the Biosolids Research Summit. Alexandria, VA: Water Environment Research Foundation.

Driedger, S.M. and Eyles, J. (2003) "Different Frames, Different Fears: Communicating about Chlorinated Drinking Water and Cancer in the Canadian Media," Social Science and Medicine 56: 1279-93.

Dunwoody, S. and Peters, H.P. (1993) "Journalistic Strategies for Reporting Long-term Environmental Issues: A Case Study of Three Superfund Sites," in A. Hansend (ed.) The Mass Media and Environmental Issues, pp. 22-50. Leicester: Leicester University Press.

Dunwoody, S. and Ryan, M. (1987) “The Credible Scientific Source,” Journalism Quarterly 64: 21-7.

Entman, R.M. (1993) "Framing: Toward Clarification of a Fractured Paradigm," Journal of Communication 43: $51-8$.

Frewer, L.J., Miles, S. and Marsh, R. (2002) "The Media and Genetically Modified Foods: Evidence in Support of Social Amplification of Risk," Risk Analysis 22(4): 701-10.

Gamson, W.A. (1989) "News as Framing," American Behavioral Scientist 33: 157-61.

Gamson, W.A. and Modigliani, A. (1989) "Media Discourse and Public Opinion on Nuclear Power: A Constructionist Approach," The American Journal of Sociology 95(1): 1-37.

Gans, H. (1979) Deciding What's News. New York: Pantheon.

Ghanem, S. (1997) "Filling in the Tapestry: The Second Level of Agenda Setting," in M. McCombs, D. Shaw and D. Weaver (eds) Communication and Democracy: Exploring the Intellectual Frontiers in Agenda-setting Theory, pp. 3-14. Mahwah, NJ: Lawrence Erlbaum.

Goldstein, N. (1998) "National Overview of Biosolids Management," BioCycle 39(12): 64-8.

Grantham, S. and Irani, T. (2004) "An Ounce of Prevention: The Role of Critical Thinking and Message Frames in Addressing Low-involvement Environmental Risks," paper presented at the 2004 Association for Education in Journalism and Mass Communication, Toronto, Canada.

Greenberg, M.R., Sandman, P.M., Sachsman, D.B. and Salomone, K.B. (1989) "Network Television News Coverage of Environmental Risks," Environment 31(2): 16-44.

Griffin, R.J. and Dunwoody, S. (1997) "Community Structure and Scientific Framing of News about Local Environmental Risks," Science Communication 18(4): 362-85.

Harrison, E.Z., McBride, M.B. and Bouldin, D.R. (1997) The Case for Caution: Recommendations for Land Application of Sewage Sludge and an Appraisal of the US EPA's Part 503 Sludge Rules. Ithaca, NY: Cornell Waste Management Institute Center for the Environment.

Hester, J.B. and Gonzenbach, W.J. (1995) “The Environment: TV News, Real-world Cues, and Public Opinion Over Time," Mass Communication Review 22(1-2): 5-21.

Huxford, J. (2000) "Framing the Future: Science Fiction Frames and the Press Coverage of Cloning," Journal of Media and Cultural Studies 14(2): 187-99.

Iyenger, S. and Kinder, D.E. (1987) News that Matters: Television and American Opinion. Chicago: University of Chicago Press.

Jockers, M. and Saroka, J. (2003) Biosolids Media Training. Portland, OR: Oregon Association of Clean Water Agencies. URL: www.oracwa.org

Kahneman, D. and Tversky, A. (1979) "Prospect Theory: An Analysis of Decision Under Risk," Econometnea 4: 263-91.

Kasperson, R.E., Renn, O., Slovic, P., Brown, H.S., Emel, J., Goble, R., Kasperson, J.X. and Ratick, S. (1988) “The Social Amplification of Risk: A Conceptual Framework," Risk Analysis 8(2): 177-87.

Liebler, C.M. and Bendix, J. (1996) "Old-growth Forests on Network News: News Sources and the Framing of an Environmental Controversy," Journalism and Mass Communication Quarterly 73(1): 53-65.

Lindsay, B.E., Zhou, H. and Halstead, J.M. (2000) "Factors Influencing Resident Attitudes Regarding the Land Application of Biosolids," American Journal of Alternative Agriculture 15(2): 88-95.

Logan, T.J. (1995) "Gaining Public Acceptance for Beneficial Use of Biosolids,” BioCycle 36(12): 61-4. 
Lundy, L.K. and Irani, T.A. (2002) "U.S. and British Media Framing of Agricultural Biotechnology.” URL: http:/ /agnews.tamu.edu/saas/2003/lundy_htm (accessed 2 August 2004).

Miller, M.M. and Riechert, B.P. (1997) "Swamped in Politics: News Coverage of Wetlands in Three Presidential Administrations," paper presented to the Association for Education in Journalism and Mass Communication, Chicago, IL.

Miller, M.M. and Riechert, B.P. (2000) "Interest Group Strategies and Journalistic Norms: News Media Framing of Environmental Issues," in S. Allan, B. Adam and C. Carter (eds) Environmental Risks and the Media, pp. 45-54. London and New York: Routledge.

National Research Council (NRC) (1996) Understanding Risk: Informing Decisions in a Democratic Society. Washington, DC: National Academy of Sciences.

National Research Council (NRC) (2002) Biosolids Applied to Land: Advancing Standards and Practices. Washington, DC: National Academies Press.

Nelkin, D. (1989) "Journalism and Science: The Creative Tension," in M. Moore (ed.) Health Risks and the Press: Perspectives on Media Coverage of Risk Assessment and Health, pp. 53-71. Washington, DC: The Media Institute.

Nelkin, D. (1995) Selling Science: How the Press Covers Science and Technology. New York: W.H. Freeman and Company.

Palenchar, M.J. (2001) "Media Coverage of Risk Events: A Framing of Comparison of Two Fatal Manufacturing Accidents," paper presented at the Association for Education in Journalism and Mass Communication, Washington, DC.

Pan, Z. and Kosicki, G.M. (2001) "Framing as a Strategic Action in Public Deliberation," in S.D. Reese, O.H. Gandy and A.E. Grant (eds) Framing Public Life: Perspectives on Media and Our Understanding of the Social World, pp. 35-65. Mahwah, NJ: Lawrence Erlbaum

Parkin, A.J. (1993) Memory: Phenomena, Experiment, and Theory. Cambridge, MA: Blackwell.

Pidgeon, N., Henwood, K. and Maguire, B. (1999) "Public Health Communication and the Social Amplification of Risks: Present Knowledge and Future Prospects," in P. Bennett and K. Calman (eds) Risk Communication and Public Health, pp. 65-77. Oxford: Oxford University Press.

Ryan, M., Dunwoody, S. and Tankard, J.W. (1991) "Risk Information for Public Consumption: Print Media Coverage of Two Risky Situations," Health Education Quarterly 18(3): 375-90.

Salomone, K.L. and Greenberg, M.R. (1990) "A Question of Quality: How Journalists and News Sources Evaluate Coverage of Environmental Risk," Journal of Communication 40(4): 117-31.

Scheufele, D.A. (1999) "Framing as a Theory of Media Effects," Journal of Communication 49(1): 103-22.

Siegrist, M. and Cvetkovich, G. (2000) "Perception of Hazards: The Role of Social Trust and Knowledge," Risk Analysis 20(5): 713-19.

Spratt, M. (2001) "Science, Journalism, and the Construction of News: How Print Media Framed the 1918 Influenza Pandemic," American Journalism 18(3): 61-79.

Stauber, J. and Rampton, S. (1995) Toxic Sludge is Good for You: Lies, Damn Lies and the Public Relations Industry. Monroe, ME: Common Courage Press.

Tankard, J.W., Jr. (2001) "The Empirical Approach to the Study of Media Framing," in S.D. Reese, O.H. Gandy and A.E. Grant (eds) Framing Public Life: Perspectives on Media and Our Understanding of the Social World, pp. 95-106. Mahwah, NJ: Lawrence Erlbaum.

Tankard, J.W., Hendrickson, L., Silberman, J., Bliss, K. and Ghanem, S. (1991) "Media Frames: Approaches to Conceptualization and Measurement," paper presented at the Association for Education in Journalism and Mass Communication, Boston, MA.

Taylor, C.E., Lee, J. and Davie, W.R. (2000) "Local Press Coverage of Environmental Conflict," Journalism and Mass Communication Quarterly 77(1): 175-92.

Tchobanoglous, G., Burton, F.L. and Stensel, H.D. (2003) Wastewater Engineering: Treatment and Reuse, 4th edn. Boston: McGraw-Hill.

United States Environmental Protection Agency (USEPA) (1999) Biosolids Generation, Use, and Disposal in the United States. EPA-530-R-99-009, September. Washington, DC: USEPA Office of Solid Waste.

United States Environmental Protection Agency (USEPA) (2000a). Clean Watersheds Needs Survey 2000 Report to Congress. Washington, DC: USEPA Office of Wastewater Management.

United States Environmental Protection Agency (USEPA) (2000b) Progress in Water Quality: An Evaluation of National Investment in Municipal Wastewater Treatment. EPA-832-R-00-008, June. Washington, DC: USEPA Office of Water.

United States Environmental Protection Agency (USEPA) (2003) Control of Pathogens and Vector Attraction in Sewage Sludge. EPA-625-R-92-013, revised July. Cincinnati, OH: USEPA Office of Research and Development. 
United States Environmental Protection Agency (USEPA) (2005) Biosolids. URL: www.epa.gov/owm/mtb/ biosolids/index.htm\#pubs

Wakefield, S.E.L. and Elliott, S.J. (2003) "Constructing the News: The Role of Local Newspapers in Environmental Risk Communication,” The Professional Geographer 55(2): 216-26.

Water Environment Foundation (WEF) (2005) Biosolids Recycling: Beneficial Technology for a Better Environment. URL: www.wef.org/PublicInfo/FactSheets/biosolidsrecycling.html

\section{Authors}

J. Robyn Goodman (Ph.D. University of Texas) is currently an Assistant Professor in the Department of Advertising at the University of Florida. Her research interests include health communication and gender depictions in media. Correspondence: PO Box 118400, Gainesville, FL 32611-8400, USA, e-mail: rgoodman@jou.ufl.edu

Brett P. Goodman (M.S. University of Iowa and P.E., professional engineer) has 10 years of experience in various water resources and environmental projects. He currently manages the environmental group for Gainesville Regional Utilities' water/wastewater engineering department. His research interests include understanding the public's acceptance of and reaction to water and wastewater utility related issues as well as conducting various engineering and scientific studies to evaluate and implement capital projects. 